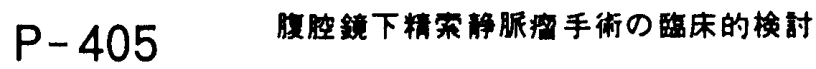

网山大学

永井敦，大枝忠史、秋山博伸，小澤秀夫。市川孝治，那須保女，公文裕已，

大森弘之

1991年10月より1994年8月までの2年10ヶ月間に47例の精索静脈溜患者に対して腹腔鏡手術を施行し， その結果につき検討を加えた。対象は男性不妊症患者が34例，陰霍内の異常を主訴とするものが13例で ある。年龄は7-43藏，平均29.3荿。患側は左46例，右1例である。手術時間は65-195分，平均105分であり， 精巣動脈の温存を原則とした。入院期間は3-13日，平均5.4日であった。初期の症例を除いて樶近ははと んど4日間の入院である。合併症は4例に認められたがいずれも皮下気腫のみで軽度であった。術後 3 力 月時における触塾では44例に静脈瘤の消失を認めた。

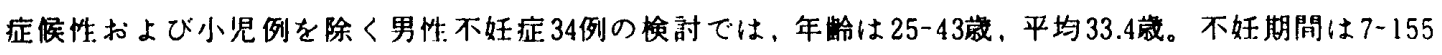

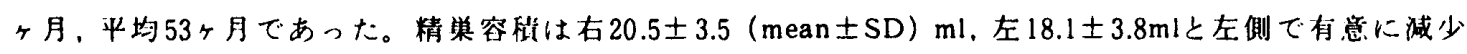

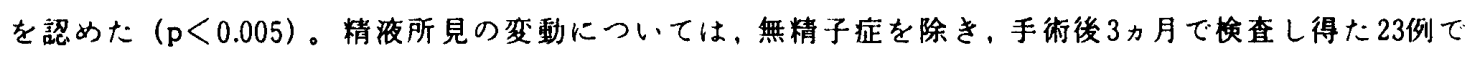

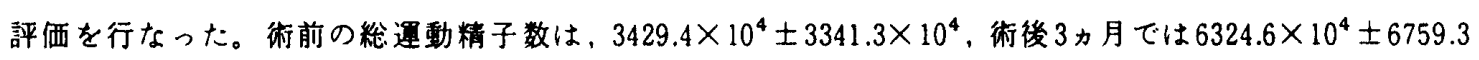
$\times 10^{4}$ であり，術後で有意に総運動精子数の增加を認めた（p<0.05）。1994年10月時点において追跡可能 であった無精子症を除く不妊症例は22例であり，その内7例に妊娠の成立を認め，妊娠率は32\%であっ た。妊娠の成立は自然妊娠が5例，AIH，IVFによるものがそれぞれ1例ずつであった。術後2年以上を経 過した症例についての娭討では12例中5例に妊娠を認めた。腹腔鏡下精索静脈䍃手術は男性不妊症に対 する有用な治療法の一つであると考えられた。

\section{$P-406$ 当科における小児に対する腹腔鏡手術の成績}

新潟大学

渡辺竜助、郷秀人、水澤隆樹、今井智之、車田茂德、武田正之

【目的】当科では1991年より腹腔鏡手術を導入した。1994年10月までに60症例に対して 腹腔鏡手術を施行した。そのうち小児（15歳以下）は28症例であり、その臨床的検即を 加えた。

【対象と結果】年秢は2歳から14藏、平均年齢6.4墄であった。nonpalpable testis18症例 (21精宩) に対し、腹垫内を観察した。うち、腹控内精单は6症例（7精巢）あり、内精 坚動脈結禁術後6力月目に二期的に精巣固定術を施行した（施行予定症例あり）。精索血 管、精管が内鼠径輪より入り込んでいる症例は12例（14精巣）あり、開放手術とし、一 期的に精巣固定をしえた症例は5症例（7精巣）であった。無精巣と低形成はそれぞれ5症 例（5精巣）、2症例（2精巣）であり、精巣摘除術を施行した。精索静脈瘤に対する内精 血管結禁術6例であり、1例に再発が認められ、8カ月後に開放手術を施行した。仮性半陰 陽、真性半陰陽、総排泄口がそれぞれ1例ずつあり性腺の腹䏶内観察、生検を施行した。 慢性腎不全患者 1 例に後㙏膜鏡による腎生検を施行した。手術時間はから15分から82分(平 均52分）であった。術中出血により、開腹手術に移行したものはなく、その他周術期に 重篤な合併症は認められなかった。

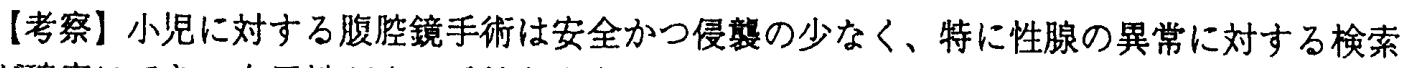
が確実にでき、有用性が忘い手技と考えられた。 